\title{
MENELUSURI SEJARAH ASAL MULA BALIKPAPAN MELALUI PERAYAAN ERAU BALIK DELAPAN Sebuah Kajian Budaya dan Folklor
}

\author{
Ulum Janah *
}

\begin{abstract}
The study on the origin of Balikpapan City through Erau Balik Delapan is factually encouraged by the cultural phenomenon along Melawai Beach. The cultural phenomenon happens there has not yet found before which has been a specific interest of the new-comers. It has been beleived that Balikapan City does not have its own culture, rather than imigrants' ones. While Erau is originated from East Kalimantan which is celebrated in areas away from East Kalimnatan, but not in Balikpapan. This ceremony is coducted with the presence of the King, the Queen, and the Kingdom's Advisor of Kutai, which is then beleived that there is a close relationship between Kutai Kingdom and Erau in Balikpapan. This research is attempted to bring about thorough explanation about the history of Balikpapan City under qualitataive research method. The data are drawn through participatory observation, in-depth interview and documentation. The data are validated by the time-triangulation technique. The result of the reserach shows the origin of Balikpapan through Erau Balik Delapan pertaining to the history, culture and legend which are still depply rooted in the community of Kutai.
\end{abstract}

Key words: Balikpapan History, Ceremony of Erau Balik Delapan

\begin{abstract}
Abstrak
Kajian tentang sejarah asal mula Kota Balikpapan melalui perayaan Erau Balik Delapan, karena adanya fenomena budaya di sepanjang Pantai Melawai. Fenomena budaya yang belum pernah terjadi sebelumnya itu menjadi perhatian masyarakat yang mayoritas pendatang. Hal tersebut karena selama ini Kota Balikpapan dikenal tidak memiliki budaya asli, yang ada ialah budaya pendatang. Sedangkan Erau sendiri merupakan salah satu kebudayaan Kalimantan Timur yang sering dirayakan di tempat tertentu lainnya di Kalimantan Timur dan bukan di Balikpapan. Selain itu perayaan tersebut juga disakralkan dengan hadirnya Sultan Kutai, Ratu Kutai, dan Penasihat Sultan, sehingga sangat menarik untuk mengetahui keterkaitan Kesultanan Kutai dengan perayaan Erau di Balikpapan. Metode penelitian ini menggunakan pendekatan kualitatif, berupa
\end{abstract}

\footnotetext{
* Ulum Janah adalah Dosen Fakultas Sastra Universitas Balikpapan
} 
deskripsi mendalam terhadap fenomena sejarah asal mula Kota Balikpapan. Pengumpulan data menggunakan participant observation, indepth interview, dan dokumentasi. Guna mencapai kredibilitas data, dilakukan cara pengamatan secara terus-menerus dan trianggulasi. Hasil penelitian menyimpulkan asal mula Balikpapan melalui Erau Balik Delapan merupakan perpaduan antara sejarah, budaya, dan legenda yang masih mengakar di masyarakat Kutai khususnya.

Kata Kunci: Sejarah Balikpapan, Perayaan Erau Balik Delapan

\section{A. PENDAHULUAN}

Bung Karno pernah menyatakan dalam satu pidatonya bahwa bangsa yang besar adalah bangsa yang menghargai sejarahnya. Hal tersebut sejalan dengan komentar Powell yaitu orang disebut kaya jika memiliki perbendaharaan kenangan, baik yang manis maupun yang pahit sehingga dapat memandang hari esok penuh harapan, melihat hari kemarin dengan rasa syukur dan memantapkan langkah di hari ini dengan mantap penuh kasih sayang dan pengertian (Supangkat, 2005). Berdasarkan acuan tersebut, sangatlah berharga mengungkap sebuah sejarah yang selama ini hanya dipandang sebagai legenda dan sejarah belaka di Indonesia khususnya Kota Balikpapan tanpa melihat kebudayaan yang ada dan mengiringi sejarah maupun legenda tersebut.

Balikpapan yang selama ini dikenal asal mulanya melalui legenda-legenda dan sejarah antara lain versi pertama dari karya Valenijn Tahun 1724 dan versi kedua berupa legenda murni yang turun- temurun dari orang-orang suku Pasir Kuleng. Hal tersebut memperkaya ragam cerita rakyat di Indonesia khususnya Kota Balikpapan. Penelusuran sejarah asal mula suatu daerah dengan adanya peristiwa sejarah sudah tentu sangat menarik untuk dibicarakan. Tetapi, bagaimana jika kisah asal mula suatu daerah tersebut dipadupadankan antara sejarah, legenda, dan suatu fenomena budaya? Hal tersebut seperti dikemukakan oleh strukturalisme Levi-Strauss yang mampu membongkar mitos masyarakat Jawa, Nyi Loro Kidul yang ternyata masih relevan dan berlaku sampai sekarang (Endraswara, 2003).

Relevansi mitos ini, misalnya dengan adanya labuhan Kraton Yogyakarta, akan mendidik sikap berkorban dan mengingat jasa leluhur. Bukti bahwa mitos itu masih ada, bisa dilihat di Parangkusuma, tempat bertemunya Panembahan Senapati dengan Nyi Loro Kidul yang masih dipercaya sampai sekarang. Prosesi labuhan yang dilakukan oleh Kraton Yogyakarta merupakan tradisi budaya yang masih melekat di kehidupan masyarakat Jawa sampai sekarang sebagai wujud hasil kebudayaan yang memiliki makna mendalam untuk menghormati dan mengingat jasa leluhur begitu pun Erau Balik Delapan di Balikpapan merupakan tradisi budaya yang juga dapat mengingatkan masyarakat akan jasa leluhur, yang pernah ada di masa lalu.

Selain itu, dengan adanya pertunjukan Erau Balik Delapan baru-baru ini di Kota Balikpapan yang dihadiri oleh Sultan Kutai dan Ratu serta Penasihat Sultan, hal tersebut: pertama akan memberikan deskripsi mengenai alasan Erau tersebut 
dirayakan di Balikpapan. Kedua, alasan Erau tersebut dinamakan Balik Delapan. Ketiga, alasan pihak Kesultanan Kutai turut hadir dalam perayaan Erau Balik Delapan di Balikpapan. Setidaknya, deskripsi pertama mengenai alasan-alasan tersebut dipaparkan oleh Bapak A. Rahim, HKA yang telah menerima SK Sultan Kutai Kartanegara Ing Martadipura, Nomor 020/SK-I/XII/2010 tentang Pengesahan Pembentukan Lembaga Adat Kutai Balikpapan dan beliau sebagai Kepala Adat Kutai atau Ketua Umum Pengurus Dewan Adat Wilayah Balikpapan. Beliau mengatakan secara lisan bahwa Erau Balik Delapan yang dirayakan Februari tahun ini merupakan tonggak sejarah asal mula Kota Balikpapan setelah kurang lebih 500 tahun Erau terakhir dilaksanakan di kota ini. Berdasarkan penjelasan tersebut, penelitian ini menjadi bertambah relevan dilakukan agar Balikpapan yang selama ini hanya dikenal sebagai kota minyak atau tambang juga mempunyai aset tambahan khususnya segi sejarah dan budaya, yang nantinya secara otomatis merambah lebih luas bagi kelangsungan pendidikan, pariwisata, dan kebudayaan itu sendiri di kota ini.

Terdapat beberapa pengertian kebudayaan menurut para ahli, pengertian tersebut antara lain dikemukakan oleh tokoh antropologi Indonesia yang terkenal yaitu Koentjaraningrat (2003) yang menyatakan bahwa kebudayaan merupakan seluruh sistem gagasan dan rasa, tindakan, serta karya yang dihasilkan manusia dalam kehidupan bermasyarakat yang dijadikan miliknya dengan belajar. Dengan demikian, hampir semua tindakan manusia adalah "kebudayaan" karena jumlah tindakan yang dilakukannya dalam kehidupan bermasyarakat yang tidak dibiasakannya dengan belajar (tindakan naluri, refleks, atau tindakan-tindakan yang dilakukan akibat sesuatu proses fisiologi, maupun berbagai tindakan membabibuta), sangat terbatas.

Sementara itu Tylor menegaskan kebudayaan adalah keseluruhan yang kompleks, yang di dalamnya terkandung ilmu pengetahuan, kepersayaan, kesenian, moral, hokum, adat istiadat, dan kemampuan yang lain serta kebiasaan yang didapat oleh manusia sebagai anggota masyarakat (Wiranata, 2011). Kelly dan Kluckhohn menyatakan kebudayaan adalah pola hidup yang tercipta dalam sejarah yang eksplisit, implisit, rasional, irasional, nonrasional yang terdapat pada setiap waktu sebagai pedoman yang potensial bagi tingkah laku manusia (Wiranata, 2011). Hal senada juga dikemukakan oleh Linton yang berpendapat bahwa kebudayaan adalah konfigurasi tingkah laku yang dipelajari dan hasil tingkah laku yang unsur pembentukannya didukung dan diteruskan oleh anggota masyarakat tertentu (Wiranata, 2011).

Suyono juga mendefinisikan kebudayaan sebagai keseluruhan hasil daya budhi cipta, karya, dan karsa manusia yang dipergunakan untuk memahami lingkungan serta pengalamannya agar menjadi pedoman bagi tingkah lakunya, sesuai dengan unsur-unsur universal di dalamnya (Wiranata, 2011). Encarta Encyclopedia mendefinisikan culture, the beliefs, behavior, language, and entire way of life of a particular time or group of people. Culture includes customs, ceremonies, works of art, inventions, technology, and traditions. The term also may have a more specific aesthetic definition and can describe the intellectual and artistic achievements of a society (Wiranata, 2011). 


\section{B. KAJIAN PUSTAKA}

\section{Wujud Kebudayaan}

Tindakan dan aktivitas manusia terangkai dalam suatu perbuatan yang berpola. Sebagai suatu sistem ide dan konsep dari serangkaian kerangka tindakan dan aktivitas manusia, tindakan tersebut menurut Parson, dkk. (Wiranata, 2011) dapat dirumuskan, yakni: ideas, activities, dan artifacts. Ideas merupakan wujud kebudayaan sebagai suatu kompleks, dari ide, gagasan, nilai, norma, dan peraturan. Sifat ini sesuai demean wujud dasarnya masih merupakan sesuatu yang abstrak dan tidak dapat digambarkan secara nyata. Sebagian masih berupa kerangka pemikiran dalam otaknya. Sebagian lain berupa kerangka perilaku yang ideal, yang memberikan corak dan jiwa, serta tatanan kehidupan yang serasi, seimbang, dan selaras. Sistem demikian ini tidak lain berupa tatanan norma ideal, pada beberapa masyarakat disebut sebagai adat atau adat istiadat, bersifat umum, dan turun temurun. Apabila dilanggar, akan menimbulkan suatu rasa yang tidak enak pada benaknya. Kalangan antropolog dan sosiolog menyebutnya sebagai sistem budaya.

Activities merupakan wujud kebudayaan sebagai suatu kompleks aktivitas serta tindakan berpola dari manusia dalam masyarakat. Termasuk dalam kategori ini adalah tatanan manusia dalam hidup bersosialisasi dan berkomunikasi serta bergaul di antara sesamanya. Berbeda dengan sistem budaya, wujud kebudayaan berpola ini sangat gampang dilihat, bahkan dapat didokumentasikan karena ia tampak nyata dalam perilaku. Artifacts merupakan wujud kebudayaan sebagai benda-benda hasil karya manusia. Wujud kebudayaan ini lebih konkret lagi dan cenderung tidak memerlukan penjelasan apa pun. Benda hasil kerajinan, misalnya, dapat dirasa, disentuh, dan difoto.

\section{Adat Istiadat}

Adat istiadat menurut Koentjaraningrat (2003) memiliki tiga sistem, yaitu: sistem nilai budaya, pandangan hidup, dan ideologi. Dari ketiga sistem tersebut, sistem nilai budaya merupakan tingkat tertinggi dan paling abstrak dari adat istiadat sebab nilai budaya terdiri dari konsep-konsep mengenai segala sesuatu yang dinilai berharga dan penting oleh warga suatu masyarakat, sehingga dapat berfungsi sebagai suatu pedoman orientasi pada kehidupan para warga masyarakat yang bersangkutan. Walaupun nilai-nilai budaya berfungsi sebagai pedoman hidup warga suatu masyarakat, sebagai konsep sifatnya sangat umum, memiliki ruang lingkup yang sangat luas, dan umumnya sulit diterangkan secara rasional dan nyata, hal itu membuat nilai budaya berada dalam daerah emosional dari alam jiwa seseorang. Suatu sistem nilai budaya seringkali merupakan suatu pandangan hidup, walaupun demikian kedua istilah itu sebaiknya tidak disamakan.

Pandangan hidup umumnya mengandung sebagian dari nilai-nilai yang dianut oleh suatu masyarakat, yang telah dipilih secara selektif oleh individuindividu dan golongan-golongan dalam masyarakat. Dengan demikian, apabila "sistem nilai" merupakan pedoman hidup yang dianut oleh suatu masyarakat, "pandangan hidup" merupakan suatu pedoman yang dianut oleh golongangolongan atau bahkan individu-individu tertentu dalam suatu masyarakat. Konsep ideologi juga merupakan suatu sistem pedoman hidup atau ciri-ciri yang ingin 
dicapai oleh para warga suatu masyarakat, namun yang sifatnya lebih khusus daripada sistem nilai budaya. Ideologi dapat menyangkut seluruh masyarakat (dalam kenyataan tentu ada pengecualian), tetapi dapat juga hanya golongangolongan tertentu saja dalam masyarakat yang bersangkutan. Sebaliknya, istilah ideologi umumnya tidak digunakan dalam hubungan dengan individu.

\section{Unsur-unsur Kebudayaan}

Unsur-unsur kebudayaan di dunia ini menurut Kluckhohn ada tujuh unsur, yakni: (1) sistem kepercayaan; (2) sistem kekerabatan dan organisasi sosial; (3) sistem mata pencaharian hidup; (4) peralatan dan perlengkapan hidup atau teknologi; (5) bahasa; (6) kesenian; dan (7) sistem pengetahuan. Sistem kepercayaan atau religi merupakan semua aktivitas manusia yang berkaitan dengan kepercayaan atau religi didasarkan pada suatu getaran jiwa, getaran jiwa ini disebut emosi keagamaan atau religious emotion. Emosi keagamaan ini umumnya pernah dialami oleh setiap orang, walaupun mungin hanya berlangsung beberapa detik saja. Religious emotion itulah yang mendorong orang melakukan tindakan-tindakan yang bersifat religi. Apabila seseorang telah dihinggapi emosi keagamaan, maka suatu benda suatu tindakan, atau suatu gagasan menjadi keramat atau dianggap keramat. Bahkan sesuatu yang umumnya tidak keramat (Profan), bila dihinggapi emosi keagamaan maka benda, tindakan, dan gagasan tadi menjadi keramat. Suatu religi dalam suatu kebudayaan selalu mempunyai cirri-ciri untuk memelihara emosi keagamaan di antara pengikut-pengikutnya. Emosi keagamaan mendorong tindakan-tindakan religi dalam hal sistem keyakinan, sistem upacara keagamaan, dan umat yang menganut religi.

Sistem kekerabatan dan organisasi sosial merupakan tatanan berupa adat-istiadat dan aturan-aturan masyarakat. Tatanan ini muncul untuk menjaga kesatuan dalam masyarakat. Kesatuan sosial yang paling dekat dan mesra adalah kesatuan kekerabatan, yaitu keluarga inti dan kaum kerabat yang lain. Kemudian, ada kesatuan-kesatuan di luar kaum kerabat, tetapi masih berada dalam lingkungan komunitas, yaitu organisasi sosial. Sistem kekerabatan terdiri atas individu-individu yang mempunyai hubungan keturunan atau hubungan darah baik bilateral atau parental maupun unilateral. Sedangkan organisasi sosial memiliki identitas kolektif yang tegas, daftar anggota yang terperinci, dan program kegiatan yang jelas. Sistem mata pencaharian hidup, merupakan perhatian para ahli antropologi terhadap berbagai macam mata pencaharian atau sistem ekonomi terbatas pada sistem yang bersifat tradisional saja. Perhatian ditujukan pada keterkaiatan antara mata pencaharian demean kebudayaan sesuatu suku bansa secara menyeluruh. Sistem mata pencaharian tersebut, yakni: (1) berburu dan meramu; (2) berternak; (3) bercocok tanam di ladang; (4) menangkap ikan; dan (5) bercocok tanam. Kelima sistem mata pencaharian tersebut, banyak dilihat dari sudut ekonominya yaitu: sistem produksi lokalnya (termasuk sumber alam dan cara mengumpulkan modal), cara pengerahan dan pengaturan tenaga kerja, teknologi produksi, sistem distribusi di pasar yang dekat, dan proses konsumsinya.

Peralatan dan perlengkapan hidup atau teknologi, bermula manusia membuat perlengkapan hidup atau teknologi sangat sederhana. Alat-alat yang 
dibuat cukup untuk dapat membantu pekerjaan pada masa itu. Banyak peralatan dibuat dari batu, tulang, dan kayu. Peralatan dan perlengkapan hidup atau teknologi dibagi dua, yakni: (1) peralatan dan perlengkapan hidup masa berburu dari kapak perimbas, alat serpih, dan alat tulang; dan (2) peralatan dan perlengkapan hidup masyarakat kecil yang berpindah-pindah atau masyarakat pertanian terdiri dari alat-alat produksi, senjata, wadah, serta makanan dan minuman, pakaian dan perhiasan, tempat berlindung dan perumahan, juga alat transportasi. Bahasa merupakan alat komunikasi. Dengan bahasa sebagai alat komunikasi, semua yang berada di sekitar manusia: peristiwa-peristiwa, binatangbinatang, tumbuh-tumbuhan, hasil cipta karya manusia, dan sebagainya, mendapat tanggapan dalam pikiran manusia, disusun dan diungkapkan kembali kepada orang-orang lain sebagai bahan komunikasi. Komunikasi melalui bahasa ini memungkinkan tiap orang menyesuaikan dirinya dengan lingkungan fisik dan sosialnya. Bahasa memungkinkan manusia mempelajari kebiasaan, adat istiadat, kebudayaan, serta latar belakangnya masing-masing. Fungsi bahasa dapat diturunkan dari dasar dan motif pertumbuhan bahasa itu sendiri. Dasar dan motif pertumbuhan bahasa itu dalam garis besar dapat berupa: (1) alat untuk menyatakan ekspresi diri; (2) alat komunikasi; (3) alat mengadakan integrasi dan adaptasi sosial; dan (4) alat mengadakan kontrol sosial.

Kesenian adalah karya cipta, rasa, dan karsa manusia untuk memberi rasa nikmat atau keindahan. Karya seni yang dimaksud adalah seni rupa, seni pertunjukan, dan sastra, yang dapat dinikmati oleh manusia demean mata dan telinga. Pembagian kesenian ini berbeda-beda sesuai demean kebutuhan dan perkembangannya. Menurut Koentjaraningrat (2002) seni drama adalah keseluruhan pembagian kesenian di atas disebabkan lapangan seni drama meliputi: seni lukis, seni rias, seni vokal (musik), seni tari, dan sastra. Sistem pengetahuan, merupakan pedoman manusia dalam kehidupan. Banyak suku bangsa di muka bumi tidak akan dapat hidup jika mereka tidak mengetahui pada musim-musim apa berbagai jenis ikan pindah ke hulu sungai dan pada musimmusim apa jenis ikan lain pindah ke hilir sungai. Manusia juga tidak akan dapat bertahan hidup jika manusia tidak mengetahui secara teliti, ciri-ciri dari bahan mentah yang mereka gunakan untuk membuat peralatan. Setiap kebudayaan selalu mempunyai seperangkat pengetahuan tentang alam, tumbuh-tumbuhan, binatang, benda, dan manusia sekitar. Pengetahuan itu berasal dari pengalaman-pengalaman yang diabstrasikan menjadi konsep teori dan pendirian. Para ahli antropologi menyadari bahwa suatu masyarakat, betapapun kecilnya, tidak mungkin dapat hidup tanpa pengetahuan mengenai alam sekelilingnya dan sifat-sifat dari peralatan yang dipakainya.

Pada pokok bahasan ini, kita menggunakan istilah pengetahuan (knowledge), bukan ilmu pengetahuan (science $=$ ilmu pengetahuan; knowledge $=$ pengetahuan), yang tersusun secara sistematis, menggunakan pemikiran dan dapat diperiksa secara kritis (obyektif). Sistem pengetahuan memiliki cabang-cabang pengetahuan setiap suku bangsa, yakni: pengetahuan tentang alam sekitar, pengetahuan tentang alam flora di daerah tempat tinggalnya, pengetahuan tentang alam fauna di daerah tempat tinggalnya, pengetahuan tentang zat-zat, bahan mentah, dan benda-benda dalam lingkungannya, pengetahuan tentang tubuh 
manusia, pengetahuan tentang sifat-sifat dan tingkah laku sesama manusia, serta pengetahuan tentang ruang dan waktu.

\section{Kebudayaan Folk}

Kebudayaan Folk oleh Redfield dianggap berada dalam masyarakat petani pedesaan pada umumnya (yaitu peasant society), tetapi juga pada penduduk kota yang bersifat rakyat umum, yaitu penduduk yang tidak termasuk golongan elite atau yang berkedudukan tinggi (Koentjaraningrat, 2002). Selain itu Redfield juga merumuskan mengenai konsep kebudayaan folk dalam emat tipe komuniti yang disebut: city (kota), town (kota kecil), peasant village (desa petani), dan tribal village (desa terisolasi). Cara Redfield menerangkan masyarakat folk dilakukan dengan membandingkannya demean masyarakat terisolasi, dan dinyatakan dengan kalimat-kalimat yang positif (lebih ini-itu) maupun dengan kalimat negatif (kurang ini-itu), seperti kurang terisolasi, lebih beraneka warna, lebih ada pembagian kerja, lebih terbuka ekonominya, kurang keramat, kurang banyak kegiatan keagamaan, kurang pengawasan kekerabatan, lebih banya pranatapranata berasas guna, kurang menganggap sakit sebagai akibat pelanggaran pantangan adat istiadat, lebih percaya kepada sihir dan guna-guna, lebih banyak memberi kesempatan kepada individu untuk memilih jalan hidupnya sendiri. Secara singkat, semua sifat komparatif itu dapat diringkas menjadi tiga ciri, yaitu: (1) pengenduran adat istiadat; (2) sekularisasi; dan (3) individualisasi.

Hal tersebut juga ditunjukkan oleh penelitian Mayer yang berupa proses kajian komuniti demean pendekatan analisis jaringan sosial dapat menelusuri kehidupan sosial dalam komuniti yang bersangkutan dari dalam, dan dari sudut perasaan, sikap, dan pandangan para individu yang menjadi warganya. Pendekatan ini tentunya berbeda dengan pendekatan yang konvensional (dari luar) yang dilakukan sebelumnya, yang umumnya dilakukan dalam penelitian antropologi, yaitu penelitian terhadap satu komunitas sebagai satu kesatuan sosial holistik yang tertutup dan terisolasi dari komuniti-komuniti lain atau dari katakota sekitarnya. Suatu komuniti seperti itu secara nyata tentu tidak ada. Semua komuniti dan komunitas tentu melakukan hubungan dengan satuan-satuan sosial lain di sekitarnya, baik melalui warganya sebagai individu, maupun melalui saluran-saluran resmi sebagai kesatuan. Hal ini telah diterangkan oleh Redfield dengan panjang lebar, dan zaman ketika para ahli antropologi memberi perhatian khusus pada sifat terisolasi dari masyarakat itu, sekarang sudah lewat (Koentjaraningrat, 2002).

\section{Interdisiplin Sejarah dan Foklor}

Endraswara (2009) menyatakan sejarah terkadang bersifat fiktif, penuh rekayasa. Hal tersebut dikarenakan sejarah sebenarnya mirip kisah. Kisah boleh dibuat-buat. Begitu pula sejarah dalam folklor. Folklor dengan sendirinya sudah bersifat imajinatif. Tentu saja dalam folklor penuh serentetan peristiwa yang imajinatif pula, meskipun bersangkut-paut dengan sejarah. Mempelajari sejarah lewat folklor, mirip belajar sejarah lewat babad. Folklor dan babad adalah senada. Keduanya memuat sumber kisah. Agar sumber kisah itu lebih terpercaya, pencipta 
babad dan folklor sering memasukkan tokoh, tempat, dan setting sejarah. Pada situasi semacam ini, berarti folklor dapat dimanfaatkan sebagai sumber sejarah.

Ahli folklor yang telah banyak membeberkan teori analisis sejarah dalam folklor adalah Vansina. Asumsi dasar dari wilayah kajian ini dalam dua jilid buku yang dia tulis berjudul Oral Tradition A Study in Historical dan Methodology Oral Tradition as History adalah, folklor merupakan sumber sejarah. Folklor diciptakan tidak lepas dari sejarah lingkungan sosial budaya. Oleh sebab itu, mengungkapkan folklor sama halnya juga menangkap aspek sejarah. Berkiblat dari Vansina, memang ada metode tersendiri yang semestinya dilakukan oleh peneliti folklor dari aspek historis. Vansina menegaskan, khususnya dalam bidang tradisi lisan dapat diingat atau dianalisis secara sastra etnologi. Maksudnya, teks folklor sebagai pembawa pesan kisah rakyat. Dari penggabungan folklor dan etnologi, yyaitu ilmu tentang etnik (bangsa), nilai historis akan terungkap. Berbagai ragam folklor dapat dijadikan berbagai sumber sejarah, seperti testimoni (kesaksian). Testimoni dalam folklor lisan amat penting, umumnya dilakukan oleh informan.

Testimoni dalam folklor dapat digali melalui berbagai tipe, antara lain slogan, ajaran, ritual, puisi, nama-nama tempat, nama pribadi, mitos, dan sejumlah keterangan dan kesaksian. Seluruh hal tersebut dapat dijadikan sumber sejarah lisan. Bahkan, hal-hal yang berisi takhayul pun amat menarik sebagai sumber sejarah. Intinya, penelitian folklor dan aspek sejarah merupakan interdisiplin yang penting dalam mewujudkan peta keilmuan. Kebenaran imajinatif pun sulit dipandang remeh karena telah lahir dari kesaksian. Kesaksian folklor dapat dilakukan oleh individu, maupun kolektif. Atas dasar ini, berarti tugas peneliti adalah mengungkap sekian banyak testimoni, yang dikaitkan demean sejarah. Mungkin sekali, sejarah tersebut sebagai sejarah lokal. Mungkin pula hal tersebut terkait dengan sejarah nasional dan internasional.

\section{METODE PENELITIAN}

\section{Penentuan Lokasi Penelitian}

Penelitian ini memilih lokasi pada waktu Erau Balik Delapan tepatnya di sepanjang Pantai Melawai. Lokasi perayaan Erau Balik Delapan ini suasananya cukup ramai mulai dari pagi sampai menjelang malam hari setiap harinya karena dekat dengan Pelabuhan Semayang yang juga berada di Teluk Balikpapan dan merupakan salah satu tempat strategis bagi pendatang masuk ke Balikpapan melalui jalur laut. Selain itu, pada saat perayaan Erau Balik Delapan dilaksanakan juga dihadiri oleh Sultan Kutai, Ratu Kutai, dan Penasihat Sultan yang meresmikan serta menyakralkan perayaan Erau Balik Delapan.

Lokasi penelitian tidak hanya dilakukan di tempat tersebut di atas melainkan juga di sekitar Landasan Hellipad depan Lapangan Merdeka. Hal ini didasarkan informasi dari informan yang merupakan Tokoh Adat Kutai, Bapak Abdul Rahim yang menyatakan bahwa tempat-tempat tersebut merupakan tonggak Sejarah Asal Mula Kota Balikpapan khususnya di Landasan Hellipad itu yang disinyalir dulunya merupakan tempat bersemedi Aji Bathara Agung Dewa Sakti setelah mengetahui dua naga Kutai berhasil mengalahkan delapan naga asing di teluk yang sekarang dikenal dengan Teluk Balikpapan. 


\section{Penentuan Informan}

Untuk menentukan informan, digunakan konsep Schutz, posisi peneliti naturalistik sebagai "orang asing" (dalam Endraswara, 2003: 39). Peneliti lebih memfokuskan pada informasi dari informan yang memiliki keterpercayaan sebagai tokoh adat Kutai di Balikpapan yang diberi mandat langsung oleh Kesultanan Kutai dan dibuktikan dengan surat keputusan (SK) yang ada. Informan pun memiliki referensi-referensi berupa dokumen-dokumen yang di dalamnya terdapat kisah tentang Balikpapan.

\section{Teknik Pengumpulan Data}

Pengumpulan data menggunakan participant observation dan indepth interview. Hal ini sangat membantu peneliti karena dapat terlibat langsung dalam pengambilan data secara terus-menerus dan hal ini diyakini untuk mendapatkan data lebih mendalam khususnya yang bersifat pribadi dengan adanya kedekatan antara peneliti dan informan yang terjalin baik. Peneliti dalam menjalankan pengamatannya langsung mendatangi tempat-tempat yang disinyalir sebagai tonggak sejarah asal mula Kota Balikpapan. Selain itu, peneliti langsung mendatangi informan yang sekaligus tokoh adat Kutai di tempat jualannya maupun di kediamannya. Observasi juga dibantu dengan foto, dokumen, dan alat perekam yang dapat menyimpan informasi dari informan, membuat penjelasan berulang, dan menegaskan pembicaraan informan serta mencocokkan informasi melalui foto-foto tempat dan dokumen yang terkait.

Wawancara sebagai salah satu cara untuk mendapatkan data dilakukan di setiap kesempatan sesuai kebutuhan data yang diperlukan. Selain itu, untuk mencapai kredibilitas data, dilakukan cara pengamatan secara terus-menerus dan trianggulasi. Pengamatan terus-menerus ditempuh dengan cara datang sesuai kebutuhan informasi yang diperlukan sampai tidak didapati informasi baru mengenai Sejarah Asal Mula Kota Balikpapan. Trianggulasi dilakukan dengan cara pengecekan ulang oleh informan setelah hasil wawancara ditranskrip.

\section{Teknik Analisis Data}

Penelitian ini menggunakan metode penelitian kualitatif yang berupa deskripsi mendalam terhadap fenomena Sejarah Asal Mula Kota Balikpapan. Dalam analisis ini, yang berbicara adalah data dan peneliti tidak melakukan penafsiran. Jika ada penafsiran, hal tersebut adalah hasil pemahaman dari interpretasi informan terhadap fenomena budaya yang telah lama tidak nampak di Kota Balikpapan disertai bukti sejarah berupa dokumen-dokumen yang dimiliki oleh informan.

Dengan demikian, pertama penelitian ini secara bertahap dapat memberikan kekhususan interpretasi mengenai sejarah asal mula Kota Balikpapan melalui perayaan Erau Balik Delapan. Kedua, penelitian ini dapat memberikan kekhususan interpretasi keterlibatan atau keterkaitan Kesultanan Kutai dengan Sejarah Asal Mula Kota Balikpapan.

\section{HASIL DAN PEMBAHASAN}




\section{Upacara Erau}

Upacara Adat Erau sudah dikenal sejak raja pertama Kutai Kartanegara, Aji Betara Agung Dewa Sakti pada tahun 1300 s.d. 1325 di Jahitan Layar Kutai Lama. Erau dalam bahasa daerah Kutai, berasal dari kata eroh yang artinya ramai, riuh, rebut, suasana yang penuh dengan suka cita. Upacara Erau awalnya dilakukan hanya untuk penobatan raja atau sultan selama 40 hari 41 malam, 24 hari 25 malam, 14 hari 15 malam, dan 7 hari 8 malam bergantung kesiapan dan kondisi kemakmuran masyarakat pada saat itu. Acara tersebut dimeriahkan berbagai kesenian, upacara-upacara adat, olahraga tradisional, dan perlombaan ketangkasan. Pada perayaan tersebut, raja atau sultan beserta kerabat keratin lainnya memberikan jamuan makan kepada rakyat yang hadir dengan memberikan pelayanan yang sebaik-baiknya, sebagai tanda terima kasih atas pengabdian rakyatnya.

Penghelatan Erau bukan berarti menghidupkan kembali kultur tradisional yang berbau feodal dari Kesultanan Kutai. Namun, pergelaran Erau merupakan salah satu dari kebhinnekaan Indonesia yang ada. Feodalisme bisa hilang dan musnah karena kecintaan terhadap Negara Kesatuan Republik Indonesia, budaya, dan kultur yang menyatu dalam kehidupan bangsa harus tetap abadi. Erau sebagai salah satu kekayaan bangsa maka tidak akan hilang begitu saja. Hal itu dapat dilihat dengan adanya kegotong-royongan yang sejak ratusan tahun lalu berakar dalam Erau. Kegotong-royongan tersebut nampak pada kesediaan suku-suku Dayak yang ada di pedalaman maupun persekutuan yang ada di pantai datang ke Tenggarong atau Kutai Lama.

Banyak budaya dan kulur ditampilkan, seperti perkawinan adat setiap suku baik Dayak Modang, Dayak Bahau, Dayak Kenyah, maupun Kutai. Selain itu, upacara pengobatan seperti Belian Sentiyu dan Belian Bawo, suku Bawo serta olah raga tradisional seperti behempas, belogo, maupun begasing yang merupakan permainan suku-suku pantai, yang banyak dilakukan oleh puak-puak melayu. Sultan dalam upacara Erau, biasanya juga memberikan anugerah gelar, pemberian tanda-tanda kehormatan, dan anugerah terhadap mereka yang berjasa terhadap negeri. Hal ini menunjukkan bahwa Erau di samping mengandung falsafah kerakyatan, demokrasi, juga merupakan falsafah kemuliaan dan rasa terima kasih negeri terhadap semua warga masyarakat. Erau sendiri terdapat dua macam yakni: (1) Erau Batu Samban; dan (2) Erau Biasa yang disebut Erau Tepong Tawar.

Erau Batu Samban berlangsung selama 21 hari dan 21 malam. Pada Erau tersebut, raja yang bersangkutan dua kali dipelas, yakni pelas pertama dilakukan berayun papan dan pelas kedua dilakukan di dekat Pinang Ayu ( Tombak Sangkoh Piatu). Tombak ini adalah tombak pusaka yang dipergunakan oleh Aji Betara Agung Dewa Sakti untuk berburu. Sepanjang yang diketahui, Erau Batu Samban sejak Betara Agung Dewa Sakti sampai sekararang hanya satu kali saja diadakan (Rachim, 2011).

Erau Biasa atau Erau Tepong Tawar dilaksanakan 14 hari dan 14 malam yang kemudian dipersingkat waktunya menjadi 7 hari 7 malam. Pada Erau tersebut, raja yang bersangkutan hanya dipelas satu kali saja, yakni di dekat Pinang Ayu (Tombak Sangkoh Piatu). Tempat peristiwa berpelas tersebut dilaksanakan di istana atau keraton. Sekitar tahun 1565, dua orang ulama yakni 
Ri Bandang dan Tunggang Parangan sampai ke Kutai. Raja-raja Kutai Kartanegara memeluk agama Islam sejak itu dan akhirnya raja berganti predikat Sultan. Namun, Erau tetap dilaksanakan sebagai warisan adat leluhur (Rachim, 2011).

\section{Kisah Erau Balik Delapan}

Perayaan Erau di Balikpapan bulan Februari 2012 bukan tanpa maksud, bukan begitu saja muncul di tengah kemajemukan masyarakat Kota Balikpapan. Namun, perayaan Erau yang diusung dengan nama Erau Balik Delapan membawa kisah tentang asal mula Balikpapan melalui kegiatan budaya. Erau di Balikpapan menurut Bapak A. Rahim, HKA, Kepala Adat Kutai atau Ketua Umum Pengurus Dewan Adat Wilayah Balikpapan secara lisan dikatakan bahwa Erau Balik Delapan yang dirayakan Februari tahun ini merupakan tonggak sejarah asal mula Kota Balikpapan setelah kurang lebih 500 tahun sekitar abad ke-13 lalu. Erau terakhir dilaksanakan di kota ini pada masa Aji Betara Agung Dewa Sakti diturunkan dari Kahyangan ke Bumi.

Hal tersebut diceritakan dalam legenda asal mula nama Balikpapan yang dirangkum oleh Lembaga Adat Kutai Balikpapan di mulai pada Zaman Batu Muda Neolitikum Masehi, yakni:

Sanghiyang Ario Banga mempunyai seorang anak laki-laki bernama Aji

Betara Agung Dewa Sakti. Aji Betara Agung Dewa Sakti diturunkan dari Jangkat / Kahyangan kebumi, maka disebutlah Dewa Kemanusan yaitu pada abad 13 Masehi. Di abad 13 inilah termaktub asal mulanya nama Balikpapan. Al kisah Pricerita, pada suatu hari dikala itu datanglah delapan (8) ekor Naga yang mencari kemala yang hilang sewaktu mereka bermainmain ditengah samudra. Kedelapan ekor Naga ini tidak diketahui dari mana asal negerinya. Naga asing itu melihat ada cahaya gemerlap dari arah pulau Kalimantan. Kedelapan Naga itu dengan beringasnya langsung berenang menuju Pulau Kalimantan karena cahaya yang mereka lihat itu disangkanya Kemala mereka yang hilang sewaktu mereka bermain-main ditengah samudra.Setibanya mereka ditengah laut yang mendekati Pulau Kalimantan, mereka berenang terus dan menghampiri cahaya yang mereka lihat tadi sampai mendekati muara sungai Mahakam.

Kedelapan ekor Naga itu melihat di muara Sungai Mahakam dipagari / dikitari oleh cahaya Pelangi dan dijaga dua ekor Naga yang bermahkota. Dengal kesalnya, kedelapan ekor Naga tadi berenang berputar-putar dimuara sungai Mahakam sehingga menimbulkan gelombang air menggunung anak besarnya. Melihat keadaan seperti itu marahlah dua ekor Naga yang menjaga muara Sungai Mahakam sehingga diserangnya delapan ekor Naga asing itu dan terjadilah pertarungan yang sangat dahsyat. Pricerita, pertarungan terjadi selama tiga hari tiga malam, dan kedelapan ekor Naga asing itu merasa kuwalahan / terdesak menghadapi dua ekor Naga penjaga muara Sungai Mahakam. Kedelapan ekor Naga asing itu mundur dan terus mundur sambil mengadakan perlawanan ala kadarnya / seadanya saja sampai ditengah laut Balikpapan (pada saat itu belum bernama teluk / laut Balikpapan). 
Di tengah-tengah laut itulah kedelapan ekor Naga asing tersebut berbalik melarikan diri menuju kearah samudra. Adapun Kemala yang mereka cari itu, timbul tenggelam dalam keadaan ketakutan dan pada akhirnya terdampar di pinggir pantai berubah ujud menjadi sebuah pulau kecil yang disebut Pulau Tokong. Dalam bahasa Kutai, Tokong itu berarti halus / kecil. Sebagai contoh, ayam kate, orang Kutai menyebutnya "mano tokong" (ayam kecil). Setelah terusirnya delapan ekor Naga asing itu, datanglah Aji Betara Agung Dewa Sakti dengan beberapa punggawanya melihat-lihat dimana tempat pertarungan dan dimana tempat berbaliknya kedelapan ekor Naga asing itu.

Setelah Aji Betara Agung Dewa Sakti mengetahui dimana tempat kedelapan ekor Naga asing itu berbalik menuju arah samudra, di tempat / ditengah laut itu lah dinamai oleh Aji Betara Agung Dewa Sakti dengan sebutan laut Balik Delapan. Kemudian Aji Betara Agung Dewa Sakti pergi menuju pantai dimana Kemala itu terdampar yang telah berubah ujud menjadi Pulau Kecil / Pulau Tokong. Aji Betara Agung Dewa Sakti langsung menghambur wija kuning / beras kuning serta membakar dupa laki bini. Disaat itulah Pulau Jelmaan / Pulau Kecil itu diberi nama Pulau Tokong / Tukung. Aji Betara Agung Dewa Sakti langsung bersemedi dan menciptakan seekor ikan yang besarnya tiada terkira untuk menjaga perairan dimana Pulau Tokong / Tukung itu berada.

Naga merupakan salah satu makhluk fiktif dalam kisah nyata, namun sangat dipercaya ada dalam kisah-kisah legenda. Begitu pun cerita naga yang dikisahkan dalam asal mula Balikpapan. Kisah asal usul Balikpapan yang melibatkan Aji Betara Agung Dewa Sakti secara otomatis juga melibatkan hal-hal yang berkaitan dengan kerabat Kutai lainnya. Hal itu dikarenakan Aji Betara Agung Dewa Sakti merupakan raja pertama Kerajaan Kutai Kartanegara di Jaitan Layar pada waktu itu. Cerita tentang naga sendiri sudah diperkenalkan melalui Sejarah Kerajaan Kesultanan Kutai Kartanegara Ing Martadipura yang disusun oleh Sultan Adji Mohammad Parikesit, Sultan Kutai, yang dibantu oleh Bapak Hafizds, yang disusun kembali oleh Adji Pangeran Hario Atmo Kesumo.

Cerita naga tersebut dimulai di Hulu Dusun yang merupakan permulaan kisah lahirnya Puti Junjung Buya atau Putri Karang Melenu. Pada saat itu dikisahkan suami istri Petinggi Hulu Dusun sangat besar hasratnya untuk mempunyai anak, mereka mengepuyakan segala cara, namun tiada diperoleh anak yang diinginkan. Sampai pada suatu ketika, mereka kehabisan kayu bakar. Petinggi pun mencari kayu, namun tiada kayu diperolehnya. Oleh karena itu, diruntuhkannya kasau laki lalu dipotongpotongnya dan dibelahnya. Sewaktu membelah kasau tersebut, didapati seekor anak sawah, kemudian dibawanyalah pulang.

Anak sawah yang diperolehnya tersebut diasuhnya seperti anak bayi. Lama-kelamaan anak sawah tersebut menjadi besar yang berubah wujud menjadi naga. Karena perubahan tersebut, kedua suami istri itu menjadi takut. Sampai suatu ketika, mereka diberi mimpi oleh seorang anak perempuan yang parasnya tiada tara untuk membuatkan tangga bagi naga 
tersebut dapat turun dari rumah. Setelah dibuatkan tangga tersebut, turunlah naga dengan diiringi kedua suami istri menuju ke tepian lalu masuk ke dalam air. Sesampai di air, maka ia pun berenang tujuh kali ke hulu dan tujuh kali ke hilir, terus menuju ke tepian batu, kemudian beredar tiga kali ke kiri, tiga kali ke kanan, kemudian ia pun tenggelam. Setelah itu, datanglah angin rebut, topan kilat, guruh petir dan halilintar yang memecahkan anak gendang telinga.

Tiada berapa lama setelah kejadian tersebut, pelangi membentang sukma, buyah pun mengumpul menyatu, maka sesaklah Sungai Mahakam karenanya. Dari buyah yang menggunung itu pun terdengar suara anak bayi. Bayi tersebut bercahaya disaput oleh awan dan dipayungi oleh mega serta dibelit oleh ketari (pelangi) dua laki bini dan teja pun membangunlah serta bertiup angin sepoi-sepoi basah antara ada dengan tiada serta hujan pun rintik-rintik dan bunga pun berkembang memenuhi pinggir pantai. Jabang bayi itu berjenis kelamin perempuan berbaring di atas gong papar yang dijunjung oleh naga-naga dan Lembu Suana yang berpijak di atas batu. Pada kelanjutannya, bayi perempuan tersebut dikenal sebagai Putri Junjung Buya atau Putri Karang Melenu.

Lembu Suana merupakan makhluk dalam mitos yang dipercaya sebagai tunggangan Aji Betara Agung Dewa Sakti dan Puteri Karang Melenu yang gerakannya sangat cepat seperti kilat. Lembu Suana memiliki cirri-ciri bergading, berbelalai dengan wajah seperti gajah, bertaring seperti macan, bersurai seperti kuda, tubuhnya seperti tubuh kuda bersayap, bertaji seperti gurda, berekor seperti naga, dan bersisik sepanjang tubuhnya. Jadi, keberadaan naga Kutai tersebut dalam legenda sudah ada mulai munculnya Putri Karang Melenu di Sungai Mahakam. Sampai sekarang, kepercayaan adanya naga yang menjaga Sungai Mahakam dan sekaligus menjaga daerah Kutai dan sekitarnya sebagai legenda terus hidup pada masyarakat Kalimantan Timur khususnya masyarakat asli yaitu Kutai dan Dayak. Kisah naga asing yang datang ke Pulau Kalimantan tersebut memang belum dapat dipastikan legendanya.

Namun, jika ditarik benang merah dari cerita Sejarah Kerajaan Kesultanan Kutai Kartanegara Ing Martadipura yang disusun oleh Sultan Adji Mohammad Parikesit halaman 12, diceritakan masa remaja Adji Betara Agung Dewa Sakti setelah dua tahun dieraukan. Ia kedatangan Raja Cina satu wangkang (perahu besar) yang mengajaknya menyabung ayam dengan taruhan wangkang, isi, serta orangnya menjadi taruhannya jika Raja Cina tersebut kalah. Namun, Jika Raja Cina menang, Adji Betara Agung Dewa Sakti menjadi budak Raja Cina. Kesepakatan pun diambil oleh Adji Betara Agung Dewa Sakti. Tetapi, dalam pelaksanaan permainan tersebut, Raja Cina berbuat curang. Ketika ayamnya kalah, ia meminta waktu kepada Aji Betara Agung Dewa Sakti, namun diam-diam ia menyuruh anak buahnya segera menjahit layar mereka yang sobek untuk segera pulang ke negaranya.

Setelah selesai dan siap kapalnya, Raja Cina dan anak buahnya berlayar. Kira-kira sampai di Laut Sangku Lirang yang pada waktu itu belum 
bernama Sangku Lirang, kapal tersebut kandas. Hal itu dikarenakan kutuk Aji Betara Agung Dewa Sakti bersangkutan dengan kelicikan Raja Cina tersebut. Seketika itu, Raja Cina dan anak buahnya lari berpencar-pencar, ada yang ke utara, ada yang ke selatan, ada yang ke barat dan menjadi basab. Mereka akhirnya berdiam dan mendirikan kampung di perbatasan Kutai dengan Berau.

Berdasarkan kutipan cerita tersebut, dapat ditarik benang merah bahwa Raja Cina yang tidak dapat kembali ke negerinya inilah yang diperkirakan membawa delapan ekor naga asing datang ke Pulau Kalimantan. Mereka datang untuk mencari rajanya yang tidak kembali dan melihat tanda berupa cahaya gemerlap dari Pulau Kalimantan yang kebetulan adalah Wilayah Kutai Lama. Namun, sesampainya di muara Sungai Mahakam, mereka telah dihadang oleh dua naga Kutai yang menjaga Sungai Mahakam sehingga terjadi pertarungan dan kedelapan naga asing tersebut kalah dan melarikan diri ke arah laut Balikpapan yang saat itu belum bernama Balikpapan.

Dikisahkan di Laut Balikpapan, kedelapan naga asing tersebut juga kalah bertanding dengan dua naga Kutai itu. Akhirnya, kedelapan naga asing tersebut balik melarikan diri ke arah samudera. Adapun cahaya gemerlap yang tak lain adalah Kemala yang mereka cari itu, timbul tenggelam dalam keadaan ketakutan dan pada akhirnya tedampar di pinggir pantai berubah ujud menjadi sebuah pulau kecil yang disebut Pulau Tokong. Dalam bahasa Kutai, Tokong itu berarti halus/ kecil. Sebagai contoh, ayam kate, orang Kutai menyebutnya "mano tokong" (ayam kecil). Setelah terusirnya delapan ekor naga asing itu, datanglah Aji Betara Agung Dewa Sakti dengan beberapa punggawanya melihat-lihat tempat pertarungan dan tempat berbaliknya kedelapan ekor Naga asing itu. Setelah Aji Betara Agung Dewa Sakti mengetahui tempat kedelapan ekor naga asing itu berbalik menuju arah samudra, di tempat atau di tengah laut itulah dinamai oleh Aji Betara Agung Dewa Sakti dengan sebutan laut Balik Delapan yang akhirnya lambat laun menjadi Balikpapan.

Kemudian Aji Betara Agung Dewa Sakti pergi menuju pantai tempat Kemala itu terdampar yang telah berubah wujud menjadi pulau kecil atau Pulau Tokong. Aji Betara Agung Dewa Sakti langsung menghambur wija kuning atau beras kuning serta membakar dupa laki bini yang diilustrasikan pada Gambar 2 . Disaat itulah pulau jelmaan atau pulau kecil itu diberi nama Pulau Tokong atau Tukung. Aji Betara Agung Dewa Sakti langsung bersemedi dan menciptakan seekor ikan yang besarnya tiada terkira untuk menjaga perairan tempat Pulau Tokong atau Tukung itu berada. Tempat bertarak tapa Aji Betara Agung Dewa Sakti sendiri disinyalir di landasan hellipad, di dekat Benua Patra. Berikut ini, gambar-gambar yang mengingatkan pada peristiwa Aji Betara Agung Dewa Sakti bertarak tapa (memohon petunjuk kepada Dewa secara spontan) pada Gambar 1 yaitu landasan hellipad yang berada pada tanda lingkaran merah, kemudian menghambur beras kuning serta membakar dupa laki bini di sepanjang Pulau Tokong pada Gambar 1 yang dideskripsikan melalui perayaan Erau oleh Sultan Kutai. 


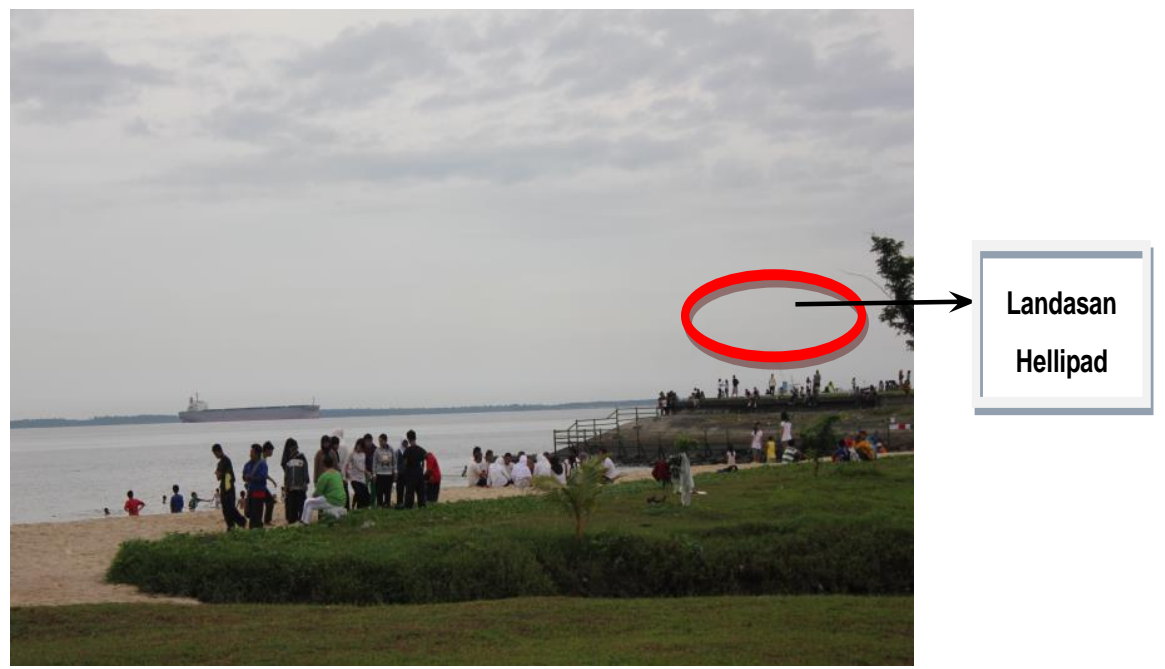

Gambar 1 Landasan Hellipad (disinyalir sebagai tempat Aji Betara Agung Dewa Sakti Bertarak Tapa)

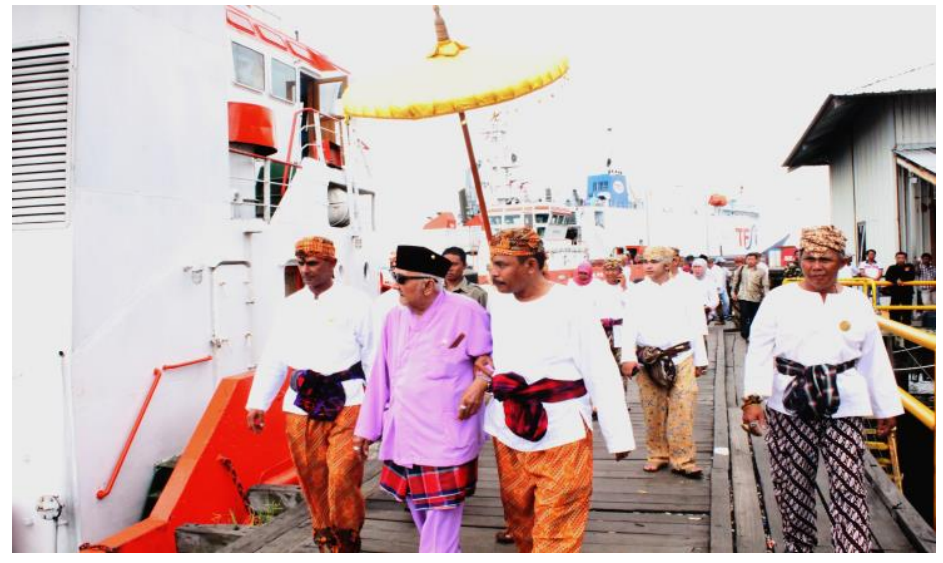

Gambar 2 Sultan Berjalan ke arah Pulau Tokong (disinyalir sebagai Lokasi Pertempuran antara Delapan Naga Asing dan Dua Naga Kutai serta Tempat AJI Betara Agung Dewa Sakti Menghambur Beras Kuning dan Membakar Dupa Laki Bini)

Jika diperhatikan cerita legenda yang dipercaya oleh masyarakat Kutai tersebut yang disampaikan melalui Erau Balik Delapan, hal itu mempunyai benang merah dengan cerita Sejarah Kerajaan Kesultanan Kutai Kartanegara Ing Martadipura yang disusun oleh Sultan Adji Mohammad Parikesit mulai lahirnya Aji Betara Agung Dewa Sakti yang merupakan titisan Dewa, Putri Karang Melenu yang lahir setelah seekor naga menenggelamkan diri di Sungai Mahakam sampai kedatangan Raja Cina yang kebetulan layarnya sobek di Jaitan Layar, tempat kekuasaan Aji Betara Agung Dewa Sakti bertahta. Selain itu, di dalam cerita yang disusun oleh Sultan Aji Mohammad Parikesit juga disebutkan beberapa daerah yang sekarang berada di bawah pemerintahan Kota Balikpapan yaitu pada cerita saat dieraukannya Aji Betara Agung Dewa Sakti. Saat itu orangorang yang diundang, yakni orang Ungkal, orang Kenangan, orang Sembera, orang Merang Kayu, orang Santan, orang Santan Dalam, orang Bontang, orang 
Kaniungan, orang Beras Basah, orang Pandan Sari, orang Gunung Kemuning, orang Rijang dan orang Tanjung Semat. Pandan Sari merupakan salah satu daerah yang disebutkan dalam cerita tersebut dan merupakan wilayah yang menjadi salah satu distrik Kota Balikpapan sekarang. Hal ini menunjukkan Balikpapan waktu itu sudah dikenal dan menjadi salah satu daerah yang terkait dengan Kutai melalui daerah tertuanya yaitu Pandan Sari.

Selain Pandan Sari, juga disebutkan daerah lain di Kota Balikpapan yang juga daerah tua kota ini. Daerah tersebut diceritakan berkaitan dengan dieraukannya Putri Karang Melenu pada Sejarah Kerajaan Kesultanan Kutai Kartanegara Ing Martadipura yang disusun oleh Sultan Adji Mohammad Parikesit halaman 9. Dikisahkan saat itu orang-orang yang diundang untuk menghadiri perayaan Erau Putri Karang Melenu, yakni orang Binalu, orang Sembaran, orang Penyuangan, orang Senawan, orang Sanga-Sangaan, orang Kembang, orang Sungai Samir, orang Dondang, orang Manggar, orang Sambuni, dan orang Tanah Malang. Dari penjelasan tersebut ada dua daerah yang saat ini masuk dalam distrik Kota Balikpapan yaitu Dondang yang sekarang adalah Samboja dan Manggar. Hal ini mulai menampakkan suatu keterkaitan cerita legenda asal usul Balikpapan yang dirangkum oleh Lembaga Adat Kutai Balikpapan dimulai pada Zaman Batu Muda Neolitikum Masehi yang disampaikan melalui Erau Balik Delapan dan mengaitkannya dengan Sejarah Kerajaan Kesultanan Kutai Kartanegara Ing Martadipura yang disusun oleh Sultan Adji Mohammad Parikesit.

\section{Keterkaitan Kesultanan Kutai dalam Erau Balik Delapan}

Perayaan Erau Balik Delapan yang merupakan erau pertama kali setelah terhenti 500 tahun lalu dilaksanakan di Balikpapan tidak akan pernah terlaksana tanpa adanya kepedulian dari setiap pihak terutama yang memiliki budaya tersebut. Salah satu pemilik kebudayaan erau yang dikenal masyarakat luas selama ini tentu saja Kesultanan Kutai. Jika melihat penjelasan tentang upacara erau sebelumnya, diketahui Upacara Adat Erau sudah dikenal sejak raja pertama Kutai Kartanegara, Aji Betara Agung Dewa Sakti pada tahun 1300 s.d. 1325 di Jahitan Layar, Kutai Lama.

Awalnya dilakukan hanya untuk penobatan raja atau sultan berikutnya berkembang dalam perayaan erau juga sultan akan memberikan anugerah gelar, memberikan tanda-tanda kehormatan, dan anugerah terhadap mereka yang berjasa terhadap negeri. Sekilas, hal tersebut menjelaskan keterkaitan Kutai dari segi erau yang mulai zaman Aji Betara Agung Dewa Sakti hadir di muka bumi. Namun, untuk lebih memperjelas keterkaitan Kutai dengan Erau Balik Delapan yang menceritakan asal-usul Balikpapan, akan diuraikan faktor-faktor: yakni: (1) berdasarkan latar belakang sejarah wilayah Kerajaan Kutai Kartanegara; dan (2) berdasarkan tanda-tanda alam yang mengungkapkan luas wilayah Kerajaan Kutai Kartanegara.

\section{Berdasarkan Latar Belakang Sejarah Wilayah Kerajaan Kutai Kartanegara}

Kerajaan Kutai Kartanegara sama halnya dengan kerajaan-kerajaan di Indonesia lainnya terutama di Jawa memiliki sejarah atas batas atau wilayah. Pada 
awal tahun 1950-an Kerajaan Kutai Kartanegara menjadi daerah otonom dengan sebutan Daerah Istimewa Kutai. Berdasarkan Undang-Undang nomor 27 tahun 1959, status Daerah Istimewa Kutai dipecah menjadi tiga daerah otonom yaitu Kabupaten Kutai, Kotamadya Samarinda, dan Kotamadya Balikpapan. Dengan demikian, dapat disimpulkan batas wilayah Kerajaan Kutai meliputi wilayah Kabupaten Kutai. Kotamadya Samarinda dan Kotamadya Balikpapan pada waktu lahir berdasarkan Undang-Undang Nomor 27 tahun 1959 tersebut. Tidak hanya itu, berikut ini akan diuraikan Wilayah Kerajaan Kutai Kartanegara mulai Zaman Belanda sampai Zaman kemerdekaan.

Zaman Belanda, secara formal Pemerintah Kolonial Belanda pertama kali menancapkan kekuasaan di Kerajaan Kutai pada tanggal 11 Oktober 1844 setelah terjadi pertempuran sengit selama lima hari, tanggal 12 April 1844. Angkatan laut Belanda di bawah pimpinan Letnan I Laut Hofd berhasil mematahkan perlawanan pasukan keamanan Kerajaan Kutai Kartanegara. Saat itulah Sultan Aji Muhammad Salehuddin menandatangani perjanjian tanda takhluk dibawah kekuasaan Belanda. Untuk mencegah Kerajaan Kutai melakukan pemberontakan, pemerintah Kolonial Belanda mengangkat H. Van Dewall menjadi Asisten Residen dan berkedudukan di Samarinda.

Sebagaimana yang terjadi di daerah Hindia Belanda lainnya, sejak saat itu di daerah Kutai, hukum tanah bersifat dualitas, yaitu status tanah yang dikuasai hukum Eropa dan status tanah yang dikuasai hukum adat. Dalam hal ini, pemerintah Hindia Belanda dalam meksanakan sistem penjajahannya telah membagi wilayah Hindia Belanda ke dalam daerah pemerintahan langsung dan daerah pemerintahan tidak langsung (landschappen atau zelfbestuuren). Hal terakhir ini adalah wilayah yang secara tradisional telah diperintah oleh raja. Pemerintah Hindia Belanda demi penghematan tetap ingin mempertahankan sistem pemerintahan tradisional itu.

Hal itu dilakukan bukan tanpa alasan. Dengan memperalat raja untuk memaksa rakyat melaksanakan keinginan pemerintahan kolonial, pemerintah Belanda dapat mencapai hal yang diinginkannya demean mudah dan yang terpenting bahwa Belanda terhindar dari kemungkinan menghadapi pemberontakan rakyat yang tertindas. Untuk mengendalikan raja, Belanda telah mengikat mereka dengan politieke contract yang berbentuk lange contracten dan korte verklaringen. Lange contracten ialah plakat panjang atau surat perjanjian panjang tentang hak Kerajaan Kutai untuk mengurus rumah tangganya sendiri disamping mengurus hal-hal lain yang berhubungan dengan kepentingan pemerintah Kolonial Belanda. Korte verklaringen ialah perjanjian pendek atau perjanjian singkat.

Untuk mengawasi pemerintah landschappen ini, pemerintah kolonial mengeluarkan zelfbestuurs regelen (peraturan penguasaan oleh Kolonial Belanda terhadap tanah jajahannya) tahun 1919. Zelfbestuurs regelen inilah yang merupakan pintu masuk bagi pemerintah Hindia Belanda untuk menguasai persoalan tanah bagi keperluan modal partikelir (penanam modal asing). Hak atas tanah bagi modal partikelir di daerah pemerintahan tidak langsung dinamakan consessie, untuk daerah pemerintahan langsung dinamakan erfpacht. Hak consessie merupakan hak perseorangan hingga tidak dapat dijadikan jaminan 
hipotek, sedangkan erfpacht merupakan hak perbendaan dan dapat dijadikan jaminan sebagai hipotek. Namun, hak consessie dapat dipindahkan atau disewakan ke tangan orang lain. Landschappen Kutai hak consessie ini pada tahun 1889 telah diberikan kepada J. H. Manten untuk pertambangan minyak di SangaSanga dan Mathilde di Balikpapan untuk eksploitasi minyak.

Berdasarkan penjelasan di atas, dapat disimpulkan wilayah Kutai Zaman Penjajahan Belanda telah mencapai Kota Balikpapan dan sebagaimana yang terjadi di daerah Hindia Belanda lainnya, sejak saat itu di daerah Kutai, hukum tanah bersifat dualitas, yaitu status tanah yang dikuasai hukum Eropa dan status tanah yang dikuasai hukum adat. Dalam hal ini, pemerintah Hindia Belanda dalam meksanakan sistem penjajahannya telah membagi wilayah Hindia Belanda ke dalam daerah pemerintahan langsung dan daerah pemerintahan tidak langsung (landschappen atau zelfbestuuren) sedangkan Kutai mengurus rumah tangganya sendiri (dalam artian di sini berkenaan dengan adat istiadat setempat) disamping mengurus hal-hal lain yang berhubungan dengan kepentingan pemerintah Kolonial Belanda.

Zaman Kemerdekaan, sebelum wafatnya Adji Sultan Muhammad Parikesit di Tenggarong (pada hari Minggu 22 Januari 1981 pukul 09.20 WITA) Kerajaan Kutai Kartanegara statusnya sebagai daerah Istimewa Kutai berakhir di Tenggarong tanggal 21 Januari 1960 pukul 11. 45 WITA. Saat itu Kepala Daerah Istimewa Kutai (A. M. Parikesit) berdasarkan undang-undang pembubaran seluruh swapraja di Indonesia dihadapan Gubernur Kaltim dan Pangdam IX Mulawarman, menyerahkan kekuasaannya kepada:

a. Bupati Kepala Daerah Kutai yang pertama berdasarkan undang-undang tersebut yaitu A. R. Padmo;

b. Walikota Kepala Daerah Kotamadya Samarinda, Kapten Sujono;

c. Walikota Kepala Daerah Kotamadya Balikpapan, A. R. S. Mohamad (Rachim, 2011: 20).

Selanjutnya memasuki kekuasaan NKRI dirumuskan pemerintahan daerah berdasarkan pasal 18 ayat 2 Undang-Undang Dasar 1945, yakni: dalam teritorial Negara Indonesia terdapat lebih kurang 250 zelfbesturende landschappen dan volksgemeenschappen, seperti desa di Jawa dan Bali, negeri di Minangkabau, dusun dan marga di Palembang dan sebagainya. Daerah-daerah itu mempunyai susunan asli, dan oleh karenanya dapat dianggap sebagai daerah yang bersifat istimewa. Negara Republik Indonesia menghormati kedudukan daerah-daerah istimewa tersebut dan segala peraturan Negara yang mengenai daerah-daerah itu akan mengingati hak-hak asal usul daerah tersebut.

Berdasarkan uraian pasal tersebut, disimpulkan hak adat masih dianggap atau diakui di daerah-daerah yang bersifat istimewa, hal tersebut termasuk Kutai. Dalam hal ini sangatlah wajar, Kesultanan Kutai mengadati daerah-daerah istimewanya seperti Balikpapan dalam perhelatan Erau Balik Delapan sehingga masyarakatnya tidak kehilangan jati diri sesuai asal usul daerahnya yang diperkuat dalam pasal di atas. Menurut Soeprapto (1986) dalam Undang-Undang Pokok Agraria yang berpangkal pada pendirian bahwa untuk mencapai apa yang ditentukan dalam pasal 33 ayat 3 UUD 1945 tidaklah perlu dan tidaklah pula pada 
tempatnya, bahwa bangsa Indonesia ataupun negara bertindak sebagai pemilik tanah. Adalah lebih tepat jika negara sebagai organisasi kekuasaan dari seluruh rakyat bertindak selaku Badan Penguasa. Hal ini dapat dilihat dari ketentuan dalam pasal 2 ayat 1 yang menyatakan bahwa: bumi, air dan ruang angkasa, termasuk kekayaan alam yang terkandung di dalamnya, pada tingkatan yang tertinggi dikuasai oleh negara.

Sesuai dengan pangkal pendirian tersebut di atas, perkataan "dikuasai" dalam pasal ini bukanlah berarti "dimiliki", akan tetapi memberi wewenang kepada negara sebagai organisasi kekuasaan dari bangsa Indonesia untuk pada tingkatan yang tertinggi: (1) mengatur dan menyelenggarakan peruntukan, penggunaan, persediaan dan pemeliharaannya; (2) menentukan dan mengatur hakhak yang dapat dipunyai atas tanah (bagian dari bumi), air dan ruang angkasa itu; dan (3) menentukan dan mengatur hubungan hukum antara orang-orang dan perbuatan-perbuatan hukum yang mengenai bumi.

Undang-Undang Pokok Agraria pasal 2 menyatakan segala sesuatunya dengan tujuan untuk mencapai sebesar-besar kemakmuran rakyat dalam rangka masyarakat yang adil dan makmur. Adapun kekuasaan negara yang dimaksud itu mengenai semua bumi, air dan ruang angkasa jadi baik yang sudah dihaki oleh seseorang maupun yang tidak. Kekuasaan negara mengenai tanah yang sudah dipunyai orang dengan sesuatu hak dibatasi oleh isi dari hak itu, artinya sampai seberapa jauh negara memberi kekuasaan kepada yang mempunyai hak untuk menggunakan haknya, sampai disitulah batas kekuasaan negara tersebut.

Kekuasaan negara atas tanah yang tidak dipunyai dengan sesuatu hak oleh seseorang atau pihak lainnya adalah lebih luas dan penuh. Dengan berpedoman pada tujuan yang disebutkan di atas, negara dapat memberikan tanah yang demikian itu kepada seseorang atau badan hukum dengan sesuatu hak menurut peruntukan dan keperluannya, misalnya hak milik, hak guna usaha, hak guna bangunan atau hak pakai atau memberikannya dalam pengelolaan kepada sesuatu Badan Penguasa (Departemen, Jawatan atau Daerah Swantantra) untuk dipergunakan bagi pelaksanaan tugasnya masing-masing. Selain itu, kekuasaaan negara atas tanah-tanah ini pun sedikit atau banyak dibatasi pula oleh hak ulayat dari kesatuan-kesatuan masyarakat hukum, sepanjang menurut kenyataannya hak ulayat itu masih ada.

Hal tersebut di atas juga sejalan dengan penjelmaan sila pertama, terdapat dalam mukadimah di bawah "BERPENDAPAT" bahwa berhubung dengan apa yang tersebut dalam pertimbangan-pertimbangan di atas perlu adanya hukum agraria nasional, yang berdasarkan atas hukum adat tentang tanah, yang sederhana dan menjamin kepastian hukum bagi seluruh rakyat Indonesia, dengan tidak mengabaikan unsur-unsur yang bersandar pada hukum agama. Hal tersebut setidaknya sebagai penguat untuk mengembangkan dan melestarikan nilai luhur budaya Indonesia yang sesuai dalam Naskah Garis-garis Besar Haluan Negara Ketetapan MPR Nomor II/MPR/1983 halaman 94 s.d. 95 bagian kebudayaan, yakni:

a. Nilai budaya Indonesia yang mencerminkan nilai luhur bangsa, harus dibina dan dikembangkan guna memperkuat penghayatan dan pengamalan 
Pancasila, memperkuat kepribadian bangsa, mempertebal rasa harga diri dan kebanggaan nasional serta memperkokoh jiwa kesatuan;

b. Kebudayaan nasional terus dibina dan diarahkan pada penerapan nilai-nilai kepribadian bangsa yang berlandaskan Pancasila;

c. Dengan tumbuhnya kebudayaan bangsa yang berkepribadian dan berkesadaran nasional maka sekaligus dapat dicegah nilai-nilai sosial budaya yang bersifat feodal dan kedaerahan yang sempit serta ditanggulangi pengaruh kebudayaan asing yang negatif, sedang di lain pihak ditumbuhkan kemampuan masyarakat untuk menyaring dan meyerap nilai-nilai dari luar yang positif dan yang memang diperlukan bagi pembaharuan dalam proses pembangunan;

d. Tanggung jawab sosial dan disiplin nasional dibina dan dikembangkan secara lebih nyata, dalam usaha untuk memperkokoh kesetiakawanan nasional, lebih menanamkan sikap mental tenggang rasa, hemat dan sederhana, bekerja keras, cermat, tertib, penuh rasa pengabdian, jujur dan kesatria;

e. Usaha-usaha pembauran bangsa perlu lebih ditingkatkan di segala bidang kehidupan baik di bidang ekonomi maupun sosial dan budaya, dalam rangka usaha memperkokoh persatuan dan kesatuan bangsa serta memantapkan ketahanan nasional;

f. Pembinaan dan pengembangan bahasa Indonesia dilaksanakan dengan mewajibkan penggunaannya secara baik dan benar;

g. Pembinaan bahasa daerah dilakukan dalam rangka pengembangan bahasa Indonesia dan untuk memperkaya perbendaharaan bahasa Indonesia dan khasanah kebudayaan nasional sebagai salah satu sarana identitas nasional;

h. Dalam pembinaan kesenian perlu dikembangkan tumbuhnya kreativitas seniman yang mencerminkan kepribadian bangsa Indonesia, serta penyediaan sarana dan prasarana yang diperlukan;

i. Pembinaan kesenian daerah ditingkatkan dalam rangka mengembangkan kesenian nasional agar dapat lebih memperkaya kesenian Indonesia yang beraneka ragam;

j. Tradisi dan peninggalan sejarah yang mempunyai nilai perjuangan bangsa, kebanggaan serta kemanfaatan nasional tetap dipelihara dan dibina untuk memupuk, memperkaya dan memberi corak khas kepada kebudayaan nasional.

Uraian tersebut cukup jelas dikaitkan dengan pernyataan Soeprapto berkenaan hak tanah ulayat baik dari Undang-Undang Pokok Agraria pasal 2, penjelmaan sila pertama pancasila serta Naskah Garis-Garis Besar Haluan Negara Ketetapan MPR Nomor II/MPR/1983 yang sangat memperhatikan nilai-nilai luhur budaya bangsa sebagai penguat penghayatan dan pengamalan Pancasila, memperkuat kepribadian bangsa, mempertebal harga diri dan kebanggaan nasional serta memperkokoh jiwa kesatuan, yang dalam hal ini juga direalisasikan oleh Kesultanan Kutai di Balikpapan dalam Erau Balik Delapan sebagai tanah ulayat yang telah dijelaskan di atas. 
Sejalan dengan hal tersebut, dapat disimpulkan pula azas dan jiwa hukum adat / hak ulayat sebagai sumber hukum menurut Soeprapto (1986) bahwa fungsi sosial hak atas tanah mengandung pengertian, yakni:

a. Fungsi sosial hak atas tanah mengandung pengertian bahwa penguasaan, pemilikan dan penggunaan tanah dijiwai oleh azas keselarasan, keserasian, dan keseimbangan dalam hubungan antara: (a) manusia dengan Tuhan dan alam lingkungan hidupnya; (b) hubungan antara sesama manusia; dan (c) hubungan antara manusia sebagai individu dengan masyarakat sebagai ajang hidupnya;

b. Memberikan hak dan kewenangan pada pemegang hak untuk memperoleh kenikmatan dan kemanfaatan demi kebahagiaan, ketentraman dan kesejahteraan hidup bagi diri sendiri dan keluarganya dalam kebersamaan dengan diri dan keluarga-keluarga lainnya sesuai dengan martabat sesama manusia serta dalam batas-batas yang tidak mengganggu dan merugikan orang lain/kepentingan umum;

c. Kewajiban memelihara, mencegah kerusakan dan meningkatkan manfaat tanah beserta alam lingkungan hidupnya;

d. Hak, kewenangan dan kewajiban menggunakan dan memanfaatkan tanah dalam keselarasan, keserasian dan keseimbangan hubungan antara kepentingan individu dengan kepentingan umum dan dalam hubungannya antara manusia dengan Tuhan dan alam semesta.

Hal-hal tersebut di atas, itulah yang dapat dijadikan penguat perhelatan Erau Balik Delapan di Balikpapan oleh Kesultanan Kutai dengan adanya hak ulayat serta fungsi sosial yang sangat selaras bagi kehidupan masyarakat di Kota Balikpapan. Sebagai bagian dari Negara Republik Indonesia, Kesultanan Kutai mencoba mengaplikasikan hal-hal yang berkenaan dengan hak ulayat yang dimiliki bersdasarkan Pancasila, Undang-Undang Pokok Agraria, UndangUndang Dasar 1945, dan GBHN yang telah dituangkan oleh pemerintah agar masyarakat Balikpapan tidak kehilangan jati dirinya dan menghargai budaya leluhurnya. Perayaan Erau Balik Delapan tersebut bukan hanya sekedar perhelatan budaya semata, namun sekaligus untuk mengenalkan kepada masyarakat Balikpapan tentang Sejarah Asal Mula Balikpapan.

\section{Berdasarkan Tanda-Tanda Alam yang Mengungkapkan Luas Wilayah Kerajaan Kutai Kartanegara}

Batas wilayah dilihat dari tanda-tanda alam ini merupakan hal yang berkenaan dengan adat istiadat dan kebudayaan masyarakat yang bermukim di wilayah tersebut. Hal itu merupakan wujud dan sekaligus unsur-unsur kebudayaan yang tidak dapat dihilangkan begitu saja, walaupun zaman telah berubah. Karena dengan kebudayaan yang masih dapat dipertahankan tersebut, suatu bangsa ataupun suatu daerah akan dipandang dan dihargai oleh bangsa atau daerah lainnya. Contoh kebudayaan yang masih dipertahankan adalah Kesultanan Yogyakarta dan Kerajaan Bali yang tidak hanya dikenal oleh seluruh masyarakat Indonesia, namun juga oleh masyarakat dunia, yang keduanya menjadi kebanggaan Indonesia serta perhatian masyarakat dunia karena kuatnya 
kebudayaan yang masih dipegang teguh dalam bentuk dan atas nama Negara Kesatuan Republik Indonesia.

Begitupun Kerajaan Kutai Kartanegara, kebudayaan ataupun adat istiadat masih dipertahankan tidak hanya di Tenggarong melainkan di daerah-daerah yang sesuai latar belakang sejarah Wilayah Kerajaan Kutai Kartanegara dulu. Wilayah Kerajaan Kutai Kartanegara tersebut menurut A. P. Ario Tjokro (Rachim, 2011) dapat ditandai melalui tanda-tanda alam, yakni:

a. Besawai, yakni: (a) bilamana ada hajat seperti erau dan lain-lain, diselenggarakan upacara adat memberitahu dan mengundang kemumulan (nenek moyang), kenjuntaian (pengaoh atau yang menjaga raja zaman purba), dan pengalasan (orang halus atau jin-jin yang menguasai Kutai) disebut "Besawai"; (b) cara besawai dengan membakar kemenyan dan wijen dipersepan atau perapen sambil mengucapkan sawai dalam bahasa Kutai tua/ keraton; dan (c) selesai besawai selalu diikuti dengan memanjatkan doa kehadirat Allah SWT bahwa besawai sekedar warisan adat leluhur, iman tetap kepada Allah SWT agar tidak ada niat syirik;

b. Tempat Kemumulan antara lain Tepian Batu, Gunung Jaitan Layar, Petong Mengkanying, Petong Mangkuaji, dan Pinang Sendawar;

c. Tempat Kejuntaian dan Pengalasan antara lain Kutai Lama, Pulau Kembang, Muara Dondang ( Samboja sekarang), Pulau Tokong, Tanjong Dewa, Tanjong Ruana, Laboan Aji, Nibung Seratus, Kumpai Menamang, Kumpai Menanjung, Loah Niung, Jantur Gemuruh, Jantur Tasik, Jantur Mapan, Loah Gagak, dan Pulau Kambing;

d. Nama-Nama Karang, seperti Karang Selimpat, Karang Teratai, Karang Paoh, Karang Genta, Karang Daulan, Karang Indera Geni, dan Karang Nungkul. Gambar beberapa karang dapat dilihat di Gambar 3.
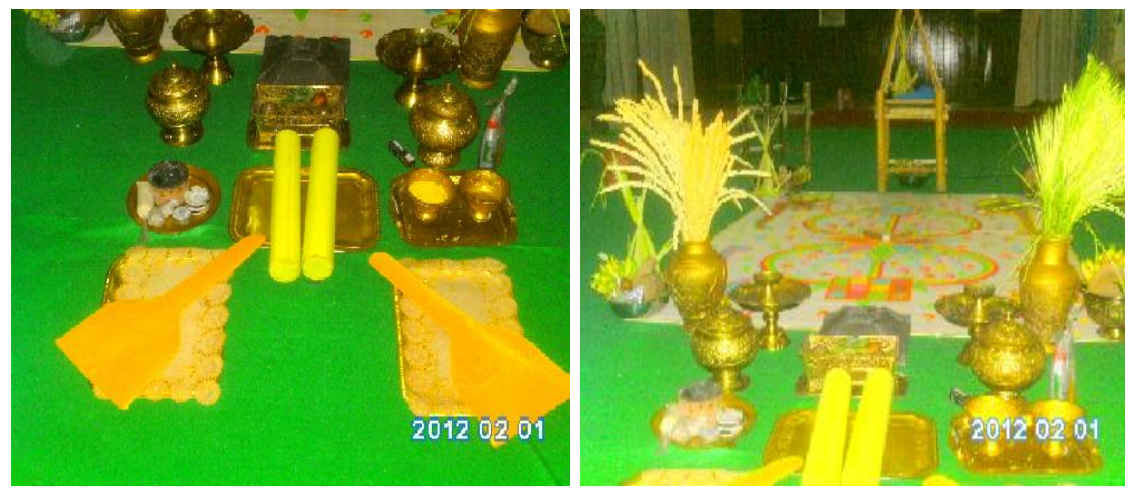

\section{Gambar 3 Karang}

Tanda-tanda alam di atas dapat dilihat dalam Upacara Erau dimulai pada acara pendahuluan, ditandai dengan mendirikan ayu yang dilaksanakan dengan beberapa kegiatan adat yaitu pertama menjamu orang halus. Menjamu orang halus dilaksanakan dengan memberikan makan atau menjamu para kemumulan dan para kejuntaian. Pada pelaksanaan menjamu para kejuntaian ini dapat dilihat Muara Dondang yang sekarang bernama Samboja dan Pulau Tokong. Kedua tempat 
tersebut merupakan bagian dari Kota Balikpapan yang telah ada dan dianggap sebagai tempat yang menjaga raja-raja Kutai mulai zaman purba.

Hal ini secara adat telah menunjukkan bahwa Kota Balikpapan merupakan bagian dari Kesultanan Kutai Kartanegara yang semestinya dan selayaknya juga dapat melestarikan kebudayaan warisan leluhur. Dengan Erau Balik Delapan yang telah dilaksanakan pada Februari 2012 lalu, dapat dilihat pula kepedulian Kesultanan Kutai terhadap daerah Balikpapan untuk mengingatkan kembali adat istiadat dan budaya yang harusnya dilestarikan oleh masyarakat Balikpapan berdasarkan riwayat tanda-tanda alam tersebut. Selain itu, pemerintah Balikpapan juga menyambut baik perayaan ini sebagai wujud kepedulian atas budaya dan adat leluhur yang pernah ada di kota ini, yang dapat dilihat dengan kehadiran Walikota dan wakilnya, Bapak Rizal dan Bapak Heru (Gambar 4).

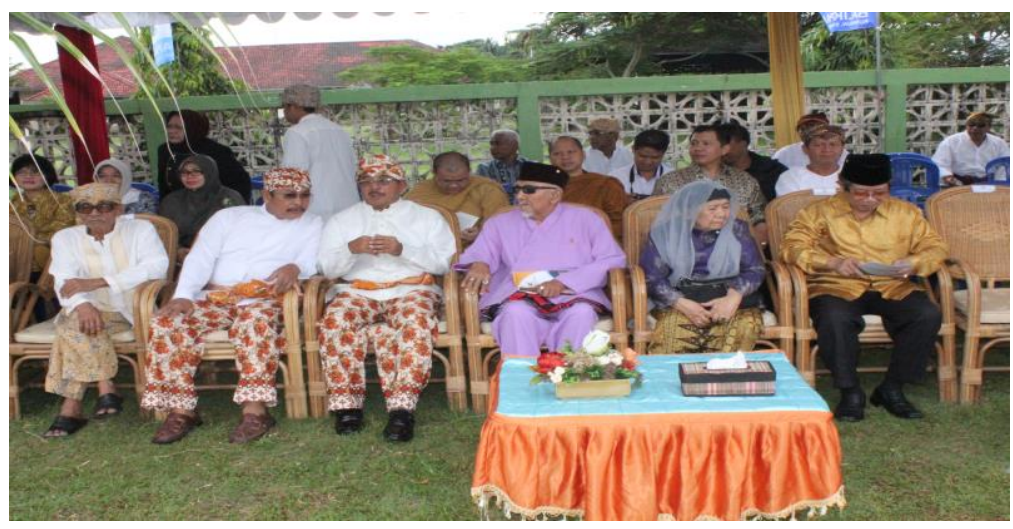

Gambar 4 Pelaksanaan Erau Balik Delapan dihadiri mulai dua dari kiri Wakil Walikota Balikpapan Bpk. Heru, Walikota Balikpapan Bpk Rizal, Sultan dan Ratu Kutai, serta mantan Walikota Balikpapan Bpk Himdad

\section{E. PENUTUP}

Berdasarkan uraian hasil penelitian dan pembahasan, disimpulkan asal mula Balikpapan melalui Erau Balik Delapan merupakan perpaduan antara sejarah, budaya, dan legenda yang masih mengakar di masyarakat Kutai khususnya. Hal-hal tersebut secara hukum yang telah diuraikan di atas, itulah yang dapat dijadikan penguat perhelatan Erau Balik Delapan di Balikpapan oleh Kesultanan Kutai dengan adanya hak ulayat serta fungsi sosial yang sangat selaras bagi kehidupan masyarakat di Kota Balikpapan. Sebagai bagian dari Negara Republik Indonesia, Kesultanan Kutai mencoba mengaplikasikan hal-hal yang berkenaan dengan hak ulayat yang dimiliki berdasarkan Undang-Undang Pokok Agraria, Undang-Undang Dasar 1945, Pancasila dan GBHN yang telah dituangkan oleh pemerintah agar masyarakat Balikpapan tidak kehilangan jati dirinya dan menghargai budaya leluhurnya.

Perayaan Erau Balik Delapan tersebut bukan hanya sekedar perhelatan budaya semata, namun sekaligus untuk mengenalkan kepada masyarakat Balikpapan tentang Sejarah Asal Mula Balikpapan. Selain itu, bersumber pada legenda, cerita asal mula Balikpapan pun telah diuraikan oleh Lembaga Adat Kutai Balikpapan yang didasarkan pada berbagai peristiwa legenda yang ditulis 
oleh Sultan Adji Mohammad Parikesit, Sultan Kutai XIX, yang dibantu oleh Bapak Hafizds, yang disusun kembali oleh Adji Pangeran Hario Atmo Kesumo. Di dalamnya pun terdapat tempat-tempat yang merupakan bagian dari Kota Balikpapan, yang saat itu menjadi wilayah kekuasaan Kutai seperti Manggar, Muara Dondang (samboja sekarang), Pulau Tokong atau Tukung, serta Pandan Sari. Tidak hanya itu, dalam sejarah sebelum kemerdekaan Balikpapan merupakan salah satu wilayah otonom pada masa Sultan Adji Mohammad Parikesit. Hal ini memperkuat pertalian Kesultanan Kutai dengan Balikpapan untuk mengetahui dan melestarikan akar budayanya. 


\section{DAFTAR RUJUKAN}

Endraswara, S. 2003. Metodologi Penelitian Kebudayaan. Yogyakarta: Gadjah Mada University Press.

Endraswara, S. 2009. Metodologi Penelitian Folklor: Konsep, Teori, dan Aplikasi. Yogyakarta: Medpress.

Coomans, Ml. 1987. Manusia Daya: Dahulu, Sekarang, Masa Depan. Jakarta: PT Gramedia.

Koentjaraningrat. 1998. Pengantar Antropologi II. Jakarta: PT Rineka Cipta.

Koentjaraningrat. 2002. Manusia dan Kebudayaan di Indonesia. Cetakan ke-19. Jakarta Djambatan.

Koentjaraningrat. 2003. Pengantar Antropologi. Jakarta: PT Rineka Cipta.

Koentjaraningrat. 1982. Kebudayaan Mentalitas dan Pembangunan. Jakarta: PT Rineka Cipta.

Rachim, A. 2011a. Beberapa Catatan Tentang Sejarah, Adat dan Budaya Kesultanan Kutai Kartanegara Ing Marta Dipura. Jilid II, Kumpulan Penelitian dan Artikel tidak diterbitkan. Balikpapan: Lembaga Adat Kutai Balikpapan.

Rachim, A. 2011b. Beberapa Catatan Tentang Sejarah, Adat dan Budaya Kesultanan Kutai Kartanegara Ing Marta Dipura. Jilid V, Kumpulan Penelitian dan Artikel tidak diterbitkan. Balikpapan: Lembaga Adat Kutai Balikpapan.

Rachim, A. Tanpa tahun. Hak Atas Tanah dan Hak Ulayat di Wilayah Bekas Kesultanan Kutai Kartanegara. Laporan Penelitian Tidak Diterbitkan. Lembaga Adat Kutai Balikpapan.

Sekretariat Negara Republik Indonesia. Tanpa tahun. Undang-Undang Dasar; Pedoman Penghayatan dan Pengamalan Pancasila Ketetapan MPR No. II/ MPR/1978; Garis-Garis Besar Haluan Negara Ketetapan MPR No. II/ $M P R / 1983$.

Soekmono. 1981. Pengantar Sejarah Kebudayaan Indonesia 1. Yogyakarta: Kanisius.

Soekmono. 1988. Pengantar Sejarah Kebudayaan Indonesia 2. Yogyakarta: Kanisius. 
Soekmono. 1989. Pengantar Sejarah Kebudayaan Indonesia 3. Yogyakarta: Kanisius.

Soeprapto. 1986. Undang-Undang Pokok Agraria; dalam Praktek. Tanpa kota dan penerbit.

Soeroso. 1988. Sejarah Peradaban Manusia Zaman Majapahit. Jakarta: PT Gita Karya.

Supangkat, M. M. 2005. Cakrawala Indonesia. Jakarta: Restu Agung.

Wiranata, I. 2011. Antropologi Budaya. Bandung: PT Citra Aditya Bakti. 